\title{
AN INVESTIGATION OF THE HIGH TWINNING RATE IN THE REPUBLIC OF IRELAND
}

\author{
GEOFFREY DEAN \\ Medico-social Research Board of Ireland \\ AND \\ THOMAS KEANE \\ Census of Population Division, Central Statistics Office, Dublin
}

The chance of having twins is greater in the Republic of Ireland than in any other country for which national statistics are available (Table I).

TABLE I

TWINNING RATES FOR DIFFERENT COUNTRIES

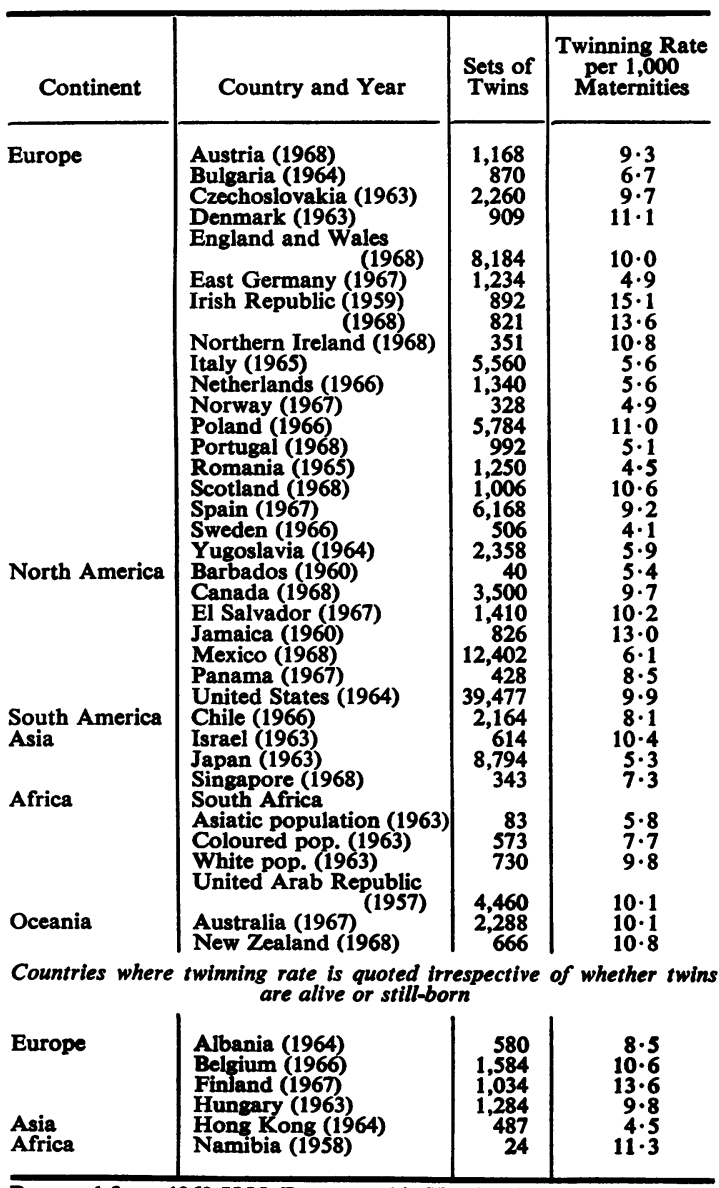

Prepared from 1969 U.N. Demographic Yearbook

In countries where medical services are less advanced the twinning rates should be treated with some caution.
However, the live twinning rate in Ireland has fallen from 1 in 66 in 1959 to 1 in 76 maternities in 1970. In the Republic of Ireland the mean live twinning rate for the ten-year period $1959-68$ was 14.5 per 1,000 or 1 in 69 maternities, and in Northern Ireland it was 12.4 or 1 in 80 (Table II). In England, Wales, and Scotland, the usual reported rate is about 1 in 90 (Bulmer, 1960). In 1968 the twinning rate in England and Wales, when both twins were alive, was 1 in 100 (Table I).

The chance of having twins increases with the mother's age up to the 35-39 age group and then decreases and increases slightly according to the number of previous pregnancies within each age group (Yerushalmy and Sheerar, 1940).

\section{Effect of Maternal Age on Twinning Rate in IRELAND}

The Vital Statistics Section of the Central Statistics Office in Ireland coded single and twin births for 1969 and 1970 by age and parity. In these two years there were 1,652 sets of twins in which both twins were alive (Table II). There was very little difference between the two years and they have therefore been grouped together and the live twin rates by age and parity have been calculated (Table III). These rates can be compared with the rates in England and Wales (Table IV). The twinning rate increases in Ireland, as elsewhere, from a very low rate under the age of $20,5 \cdot 8$ pairs of twins per 1,000 maternities, to $19 \cdot 6$ pairs of twins per 1,000 in the $35-39$ age group, and falls over the age of 40 to $12 \cdot 8$ per $1,000(40-44,13 \cdot 0$; 45 and over, $11 \cdot 0$ ). In each age group over 20 the rates are higher in the Republic of Ireland than in England and Wales.

During the years 1969-70 the twinning rate in the Republic of Ireland was 13.4 per 1,000 , or 1 in 74 pregnancies. The twinning rate is highest in Connacht (15.9 per 1,000 maternities, 1969) and lowest in Leinster $(13.1$ per 1,000 maternities, 
TABLE II

NUMBER OF MULTIPLE BIRTHS IN REPUBLIC OF IRELAND AND NORTHERN IRELAND 1959-68 AND TWINNING RATE PER 1,000 PREGNANCIES

\begin{tabular}{|c|c|c|c|c|c|c|}
\hline Year & $\begin{array}{c}\text { Live } \\
\text { Births }\end{array}$ & $\begin{array}{l}\text { Maternities } \\
\text { Resulting in } \\
\text { Live Issue }\end{array}$ & Twins & Triplets & Quadruplets & $\begin{array}{c}\text { Twinning } \\
\text { Rate per } \\
1,000 \\
\text { Pregnancies }\end{array}$ \\
\hline $\begin{array}{c}\text { Republic of } \\
1959 \\
1960 \\
1961 \\
1962 \\
1963 \\
1964 \\
1965 \\
1966 \\
1967 \\
1968\end{array}$ & $\begin{array}{l}60,188 \\
60,735 \\
59,825 \\
61,782 \\
63,246 \\
64,072 \\
63,525 \\
62,215 \\
61,307 \\
61,004\end{array}$ & $\begin{array}{l}59,268 \\
59,817 \\
58,902 \\
60,826 \\
62,264 \\
63,177 \\
62,648 \\
61,39 \\
60,457 \\
60,165\end{array}$ & $\begin{array}{l}892 \\
896 \\
911 \\
926 \\
960 \\
873 \\
850 \\
858 \\
836 \\
821\end{array}$ & $\begin{array}{c}14 \\
11 \\
6 \\
12 \\
21 \\
11 \\
12 \\
9 \\
7 \\
9\end{array}$ & $\begin{array}{l}\bar{z} \\
\frac{2}{7} \\
\frac{1}{z}\end{array}$ & $\begin{array}{l}15.1 \text { (1 in } 66) \\
15.0 \text { (1 in } 67) \\
15.5 \text { (1 in } 65) \\
15.2 \text { (1 in } 66) \\
15.6 \text { (1 in } 65) \\
13.8(1 \text { in } 72) \\
13.6 \text { (i i 7 } 74) \\
14.0(1 \text { in } 71) \\
13.8(1 \text { in } 72) \\
13.6(1 \text { in } 73)\end{array}$ \\
\hline $\begin{array}{l}\text { Total } \\
1959 / 68\end{array}$ & 617,899 & 608,863 & 8,823 & 102 & 3 & $14.5(1$ in 69$)$ \\
\hline $\begin{array}{l}\text { Average } \\
1959 / 68\end{array}$ & 61,790 & 60,886 & 882 & 10 & - & $14.5(1$ in 69$)$ \\
\hline $\begin{array}{l}1969 \\
1970\end{array}$ & & $\begin{array}{l}62,064 \\
60,837\end{array}$ & $\begin{array}{l}849 \\
803\end{array}$ & & & $\begin{array}{l}13 \cdot 7(1 \text { in } 73) \\
13 \cdot 2\left(\begin{array}{l}1 \text { in } 76)\end{array}\right.\end{array}$ \\
\hline $\begin{array}{l}\text { Average } \\
1969 / 70\end{array}$ & & 61,450 & 826 & & & 13.41 in 74$)$ \\
\hline \multicolumn{7}{|c|}{ Northern Ireland } \\
\hline $\begin{array}{l}1959 / 63 \\
1964 / 68\end{array}$ & & $\begin{array}{l}158,520 \\
165,839\end{array}$ & $\begin{array}{l}2,172 \\
1,864\end{array}$ & & & $\begin{array}{l}13 \cdot 7\left(\begin{array}{l}1 \text { in } 73) \\
11.2( \\
1 \text { in } 89\end{array}\right)\end{array}$ \\
\hline $\begin{array}{l}\text { Average } \\
1959 / 68\end{array}$ & & 32,436 & 404 & & & $12.4(1$ in 80$)$ \\
\hline
\end{tabular}

TABLE III

LIVE TWIN MATERNITY RATES BY AGE AND PARITY:

REPUBLIC OF IRELAND AVERAGE 1969/70

\begin{tabular}{|c|c|c|c|c|c|c|c|c|}
\hline \multirow{2}{*}{ Parity } & \multicolumn{8}{|c|}{ Age at Maternity } \\
\hline & Under 20 & $20-24$ & $25-29$ & $30-34$ & $35-39$ & $40+$ & Unknown & Total \\
\hline $\begin{array}{l}0 \\
1 \\
2 \\
3 \\
4 \\
5+\end{array}$ & $\begin{array}{l}6.3 \\
4.6 \\
= \\
=\end{array}$ & $\begin{array}{r}8 \cdot 0 \\
8 \cdot 1 \\
11 \cdot 6 \\
10 \cdot 3 \\
7 \cdot 3 \\
11 \cdot 2\end{array}$ & $\begin{array}{l}12 \cdot 3 \\
11 \cdot 0 \\
12 \cdot 7 \\
12 \cdot 9 \\
14 \cdot 3 \\
15 \cdot 3\end{array}$ & $\begin{array}{l}17 \cdot 5 \\
14 \cdot 2 \\
16 \cdot 1 \\
15.4 \\
19.7 \\
19 \cdot 3\end{array}$ & $\begin{array}{l}16 \cdot 4 \\
18 \cdot 3 \\
16 \cdot 9 \\
18 \cdot 4 \\
16 \cdot 7 \\
23 \cdot 1\end{array}$ & $\begin{array}{r}8 \cdot 5 \\
13 \cdot 5 \\
5 \cdot 1 \\
6 \cdot 0 \\
12 \cdot 2 \\
15 \cdot 6 \\
\end{array}$ & $\begin{array}{l}8 \cdot 1 \\
= \\
=\end{array}$ & $\begin{array}{l}10.4 \\
11.1 \\
13.8 \\
14.4 \\
16.5 \\
19.4\end{array}$ \\
\hline \multirow{3}{*}{$\begin{array}{l}\text { All parities } \\
\text { Total twin } \\
\text { maternities } \\
\text { Total } \\
\text { maternities }\end{array}$} & $5 \cdot 8$ & $8 \cdot 5$ & $12 \cdot 3$ & $16 \cdot 8$ & $19 \cdot 6$ & $12 \cdot 8$ & 6.4 & $13 \cdot 4$ \\
\hline & 23 & 236 & 443 & 478 & 371 & 97 & 4 & 1,652 \\
\hline & 3,953 & 27,623 & 35,883 & 28,369 & 18,898 & 7,550 & 625 & 122,901 \\
\hline
\end{tabular}


TABLE IV

LIVE TWIN MATERNITY RATES BY AGE AND PARITY: ENGLAND AND WALES 1968

\begin{tabular}{|c|c|c|c|c|c|c|c|}
\hline \multirow{2}{*}{$\begin{array}{l}\text { No. of Previous } \\
\text { Liveborn Children }\end{array}$} & \multicolumn{7}{|c|}{ Age at Maternity } \\
\hline & Under 20 & $20-24$ & $25-29$ & $30-34$ & $35-39$ & $40+$ & All Ages \\
\hline $\begin{array}{l}0 \\
1 \\
2 \\
3 \\
4 \\
5+\end{array}$ & $\begin{array}{r}5.9 \\
6.4 \\
9.7 \\
= \\
=\end{array}$ & $\begin{array}{r}7 \cdot 4 \\
8.8 \\
10 \cdot 3 \\
8.9 \\
6 \cdot 2 \\
8 \cdot 2\end{array}$ & $\begin{array}{r}8.9 \\
10.3 \\
11 \cdot 7 \\
13 \cdot 0 \\
10 \cdot 7 \\
13 \cdot 3\end{array}$ & $\begin{array}{l}12 \cdot 3 \\
12 \cdot 7 \\
13 \cdot 3 \\
12 \cdot 8 \\
13 \cdot 8 \\
18 \cdot 0\end{array}$ & $\begin{array}{l}14 \cdot 9 \\
14 \cdot 2 \\
12 \cdot 8 \\
16 \cdot 9 \\
18 \cdot 3 \\
17 \cdot 4\end{array}$ & $\begin{array}{r}12.6 \\
8.3 \\
6.6 \\
9.5 \\
9.5 \\
11.9\end{array}$ & $\begin{array}{r}8.0 \\
10.0 \\
11.7 \\
13.0 \\
13.3 \\
16 \cdot 1\end{array}$ \\
\hline All parities & $6 \cdot 0$ & $8 \cdot 2$ & $10 \cdot 5$ & $13 \cdot 3$ & $15 \cdot 4$ & $9 \cdot 7$ & $10 \cdot 1$ \\
\hline $\begin{array}{l}\text { Total twin maternities } \\
\text { Total maternities }\end{array}$ & $\begin{array}{r}363 \\
60,266\end{array}$ & $\begin{array}{r}2,235 \\
271,583\end{array}$ & $\begin{array}{r}2,397 \\
229,123\end{array}$ & $\begin{array}{r}1,573 \\
118,696\end{array}$ & $\begin{array}{r}832 \\
54,193\end{array}$ & $\begin{array}{r}151 \\
15,605\end{array}$ & $\begin{array}{r}7,551 \\
749,466\end{array}$ \\
\hline
\end{tabular}

Rates are based on the numbers of legitimate twin maternities (where both children were born alive) per 1,000 legitimate live births. The total number of twin maternities (where both children were born alive) was 8,184 .

1969). The age distribution of pregnancies in Ireland is different from that in England and Wales and in other countries because, owing to the late average age at marriage and larger average family size, there are relatively more pregnancies over the age of 30 .

In the Republic of Ireland in 1969-70 there were 1,652 sets of twins, where both children were born alive, out of 122,901 maternities (Table III). If Ireland had had the twinning rates of England and Wales (Table IV) in each age parity group we would have 'expected' 1,423 sets of twins; 229 sets of twins are, therefore, accounted for by the higher twinning rates in Ireland $(1,652-1,423)$.

The Irish mothers had more children at older ages than the English mothers. If the Irish mothers had had the 122,901 maternities in the same age, parity distribution, and rates as the English mothers, 1,238 sets of twins would have been 'expected'; 185 sets of twins are, therefore, accounted for by the higher age and, to a very small extent, higher parity of the Irish mothers $(1,423-1,238)$.

The higher Irish twinning rates are, therefore, due in approximately equal parts to the higher twinning rates in Ireland than in England and Wales and to the higher proportion of babies that are born to Irish mothers in the later age groups. In the Republic of Ireland, $40.4 \%$ of births occur in women aged 30-39 compared with $22.4 \%$ in England and Wales (1968) (Table V). The median age of brides at first marriage has fallen in Ireland from 27.0 in 1946 to 23.9 in 1968 . The age at marriage was higher in rural than in urban areas (Table VI). The fall in the age of marriage for grooms is greater than for brides, so there is on average less difference in age between husband and wife. The average size of the Irish family is also falling, but in Ireland families are still considerably bigger than in England
TABLE V

PERCENTAGE DISTRIBUTION OF BIRTHS BY AGE OF MOTHER AT MATERNITY IN IRELAND AND ENGLAND AND WALES, 1956 AND 1968

\begin{tabular}{l|rr|rr}
\hline \multirow{2}{*}{ Age } & \multicolumn{3}{|c|}{ Ireland } & \multicolumn{2}{c}{ England and Wales } \\
\cline { 2 - 3 } & \multicolumn{1}{|c|}{1956} & 1968 & 1956 & 1968 \\
& & & & \\
\hline Under 20 & 1.8 & 2.9 & 5.4 & 10.0 \\
$20-24$ & 13.4 & 21.2 & 29.1 & 36.1 \\
$25-29$ & 26.0 & 28.6 & 31.8 & 29.4 \\
$30-34$ & 28.8 & 23.7 & 20.4 & 15.3 \\
$35-39$ & 8.4 & 16.7 & 10.1 & 7.1 \\
$40-44$ & 6.1 & 6.3 & 2.9 & 1.9 \\
45 and over & 0.5 & 0.6 & 0.2 & 0.1 \\
& & & & \\
\hline All ages & 100.0 & 100.0 & 100.0 & 100.0 \\
Average age & 31.6 & 30.1 & 28.0 & 26.0 \\
\hline
\end{tabular}

and Wales. The lower socio-economic groups have families that are $50 \%$ greater in size than the highest socio-economic group-self-employed professional workers. This difference in size of family between socio-economic group is much less in England and Wales (Table VII).

Ireland has fewer live births to mothers in the younger age groups than most other catholic countries. Spain also has proportionately few births to mothers under the age of $30,55 \%$ (1967) compared with the Republic of Ireland $52 \%$ (1968) (Table VIII), although the reported live twinning rate in Spain is low, $9 \cdot 2$ per 1,000 maternities in 1967 (Table I). Medical services and the survival of twins differ, of course, from country to country, which is why Ireland can best be compared with England and Wales.

The proportion of triplets among all deliveries is approximately the square of the proportion of twins among all pregnancies. The triplet rates show the same relationship by age and parity as twin rates (Zeleny, 1921). Between 1959 and 1968 
TABLE VI

MEDIAN AGE OF BRIDES AND GROOMS AT FIRST MARRIAGE, IRELAND 1946 AND $1957 / 68$

\begin{tabular}{|c|c|c|c|c|c|c|c|c|c|c|c|c|c|c|c|}
\hline Year & & $1946^{*}$ & & 1957 & 1958 & 1959 & 1960 & 1961 & 1962 & 1963 & 1964 & 1965 & 1966 & 1967 & 1968 \\
\hline Brides & $\begin{array}{c}\text { Urban } \\
25 \cdot 8\end{array}$ & $\underset{28 \cdot 0}{\text { Rural }}$ & $\begin{array}{l}\text { Total } \\
27 \cdot 0\end{array}$ & 25.9 & $25 \cdot 7$ & $25 \cdot 4$ & $25 \cdot 3$ & $25 \cdot 1$ & 24.9 & $24 \cdot 6$ & $24 \cdot 5$ & $24 \cdot 2$ & $24 \cdot 0$ & $24 \cdot 0$ & 23.9 \\
\hline Grooms & $29 \cdot 2$ & $33 \cdot 6$ & $31 \cdot 8$ & $29 \cdot 4$ & $29 \cdot 2$ & 28.9 & $28 \cdot 6$ & $28 \cdot 3$ & $27 \cdot 9$ & $27 \cdot 7$ & $27 \cdot 4$ & $27 \cdot 0$ & $26 \cdot 9$ & $26 \cdot 6$ & $26 \cdot 3$ \\
\hline
\end{tabular}

*All marriages, including remarriages. Based on the 14,338 usable returns from the 1946 Census. The total number of marriages in the preceding 12 months was 17,859 .

TABLE VII

FIGURES RELATING TO NUMBER OF CHILDREN PER 100 MARRIAGES OF 20-24 YEARS' DURATION: WIVES AT TIME OF MARRIAGE 20-24 YEARS: OFFICIAL CENSUS TIME OF MARRIAGE 20-24 YEARS
RETURNS

\begin{tabular}{l|c|ccc|c}
\hline \multicolumn{1}{c|}{ Social Group } & $\begin{array}{c}\text { Trish } \\
\text { 1946 } \\
\text { Average }\end{array}$ & \multicolumn{3}{|c|}{ Trish 1961 } & $\begin{array}{c}\text { English } \\
\text { 1961 } \\
\text { Average }\end{array}$ \\
\cline { 5 - 6 } & Average Catholic & Other & \\
\hline $\begin{array}{l}\text { Professional workers, } \\
\text { self-employed }\end{array}$ & 387 & 382 & 437 & 265 & 238 \\
$\begin{array}{l}\text { Professional workers, } \\
\text { employees }\end{array}$ & 501 & 435 & 460 & 249 & 204 \\
$\begin{array}{l}\text { Employers and } \\
\text { managers }\end{array}$ & 427 & 386 & 429 & 267 & $194 *$ \\
$\begin{array}{l}\text { Farmers, relatives, } \\
\text { farm managers }\end{array}$ & 591 & 581 & 596 & 404 & $247^{*}$ \\
$\begin{array}{l}\text { Agricultural workers, } \\
\text { fishermen }\end{array}$ & 609 & 573 & 577 & 428 & 260 \\
$\begin{array}{l}\text { Skilled manual } \\
\text { workers }\end{array}$ & 574 & 524 & 533 & 328 & 219 \\
$\begin{array}{l}\text { Semi-skilled } \\
\text { manual workers }\end{array}$ & 629 & 548 & 551 & 332 & 229 \\
$\begin{array}{l}\text { Unskilled manual } \\
\text { workers }\end{array}$ & 629 & 608 & 610 & 420 & 256 \\
\hline
\end{tabular}

* Mean figures of two subgroups

we would have 'expected' approximately 128 sets of triplets in Ireland; 102 sets were registered (Table II). Other studies have also shown that the 'expected' number, derived on this basis from the number of twins, is usually slightly higher than the actual number of sets of triplets (Zeleny, 1921).

\section{EfFect of Parity on Twinning in Ireland}

It has been reported elsewhere that in each age group there is a higher rate of twinning for high parity (Yerushalmy and Sheerar, 1940). In Ireland the difference is not marked, but if mothers who have had no previous pregnancies are compared with those who have had more than five previous pregnancies, the twinning rate is slightly higher in each age group in those mothers who have had five or more children.

In order to study the effect of parity within each five-year age group the number of twins that would occur if there was no increase with parity can be calculated by using the twinning rate in each age group for nil parity. In Ireland, if the twinning rates in each age group were those of nil parity, that is of the first baby, the number of twins would be reduced from 1,652 to 1,563 (1969-70), a reduction of $5.3 \%$, and in England and Wales the number of legitimate twins would be reduced from 7,551 to 6,869 (1968), a reduction of $90 \%$. It must also be remembered that within each five-year age group there will also be a correlation between parity and age, and, therefore, within each age group there will be a weak and spurious correlation between parity and the twinning rate. In both Ireland and England and Wales there is, therefore, a small increase in the twinning rates with increased parity within each age group, but this increase in the twinning rate within each age group with higher parity is partly spurious and in any case it makes only a small contribution to the total twinning rate.

TABLE VIII

DISTRIBUTION OF LIVE BIRTHS BY MOTHER'S AGE AT MATERNITY (\% IN AGE GROUP)

\begin{tabular}{|c|c|c|c|c|c|c|c|c|c|}
\hline & \multicolumn{9}{|c|}{ Mother's Age } \\
\hline & All Ages & $15-19$ & $20-24$ & $25-29$ & $30-34$ & $35-39$ & $40-44$ & $45-49$ & Unknown \\
\hline \multirow{2}{*}{$\begin{array}{l}\text { Ireland, } 1968 \\
\text { Italy, 1967 } \\
\text { Portugal, } 1967 \\
\text { Spain, 1968 } \\
\text { Yugoslavia, } 1967 \\
\text { France, 1967 } \\
\text { Fed. Rep. } \\
\text { Germany, } 1967\end{array}$} & $\begin{array}{l}100 \\
100 \\
100 \\
100 \\
100 \\
100\end{array}$ & $\begin{array}{r}2.9 \\
9.0 \\
5.7 \\
2.6 \\
12.8 \\
6.4\end{array}$ & $\begin{array}{l}21 \cdot 1 \\
21 \cdot 1 \\
25 \cdot 6 \\
22 \cdot 3 \\
31 \cdot 6 \\
33 \cdot 3\end{array}$ & $\begin{array}{l}28 \cdot 4 \\
32 \cdot 2 \\
27 \cdot 6 \\
30 \cdot 1 \\
27 \cdot 6 \\
27 \cdot 7\end{array}$ & $\begin{array}{l}23 \cdot 6 \\
21 \cdot 4 \\
20 \cdot 8 \\
24 \cdot 1 \\
16 \cdot 7 \\
18 \cdot 6\end{array}$ & $\begin{array}{r}16 \cdot 6 \\
11 \cdot 5 \\
13 \cdot 6 \\
14 \cdot 7 \\
8 \cdot 2 \\
9.9\end{array}$ & $\begin{array}{l}6 \cdot 3 \\
3 \cdot 5 \\
5 \cdot 7 \\
4 \cdot 7 \\
2 \cdot 3 \\
3 \cdot 0\end{array}$ & $\begin{array}{l}0 \cdot 5 \\
0 \cdot 3 \\
0 \cdot 5 \\
0 \cdot 4 \\
0 \cdot 4 \\
0 \cdot 2\end{array}$ & $\begin{array}{l}0.5 \\
1.0 \\
0.4 \\
1.0 \\
0.2 \\
0.9\end{array}$ \\
\hline & 100 & $6 \cdot 5$ & $26 \cdot 8$ & $35 \cdot 2$ & $20 \cdot 2$ & $8 \cdot 5$ & $2 \cdot 6$ & $0 \cdot 2$ & - \\
\hline
\end{tabular}

Data source: U.N. Demographic Yearbook (1969), Table 14. 
Twinning Rates at Dublin Maternity Hospitals

The Masters of the Coombe, the National Maternity, and the Rotunda Hospitals in Dublin co-operated with this study by providing statistics of twin births and of deliveries of 28 weeks and over. The average live twinning rate for these three hospitals for $1968-69$ was 15.4 per 1,000 or 1 in 65 pregnancies (Table IX). The twinning rate in the hospitals is falling and is remarkably consistent between the hospitals. The twinning rate at Galway Regional Hospital is $17 \cdot 7$ per 1,000 , or 1 in 56 pregnancies (Mooney, 1970).

In the Dublin hospitals the chance of having twins also increases with the age of the mother up the 35-39 age group and then falls after the age of 40 (Table X). The chance of having twins is higher in the Dublin maternity hospitals than in the general population, 1 in 65 maternities with 1 in 73 (1968-69), perhaps because mothers who have twins are more likely to be admitted to a Dublin maternity hospital, both from Dublin city and from country areas, than mothers with single pregnancies. The percentage in the 30-39 age group admitted to maternity hospitals is much the same as in the general population. In the National Maternity and Rotunda Hospitals the proportion of twins where one twin was deadborn was 43 out of 964 twin births (1963-67), or $4.5 \%$.

\section{IDENTICAL AND NoN-IDENTICAL TwINS}

A statistical method developed by Weinberg makes it possible to find out approximately how many twins in a twin-population are monozygotic and how many are dizygotic (Weinberg, 1909).
TABLE IX

TWINNING IN THREE DUBLIN MATERNITY HOSPITALS

\begin{tabular}{|c|c|c|c|c|}
\hline Hospital & $\begin{array}{c}\text { Total } \\
\text { Deliveries } \\
\text { after } 28 \\
\text { Weeks }\end{array}$ & $\begin{array}{l}\text { Twin } \\
\text { Births }\end{array}$ & $\begin{array}{l}\text { Twin } \\
\text { Incidence } \\
\% \text { and per } \\
1,000 \\
\text { Deliveries }\end{array}$ & Rate \\
\hline $\begin{array}{l}1968 \\
\text { Rotunda } \\
\text { Coombe } \\
\text { National }\end{array}$ & $\begin{array}{l}5,340 \\
5,596 \\
4,751\end{array}$ & $\begin{array}{l}79 \\
88 \\
84\end{array}$ & $\begin{array}{l}1.5(14 \cdot 8) \\
1.6(15 \cdot 7) \\
1.8(17 \cdot 7)\end{array}$ & $\begin{array}{l}1 \text { in } 68 \\
1 \text { in } 64 \\
1 \text { in } 57\end{array}$ \\
\hline Total & 15,687 & 251 & $1 \cdot 6(16 \cdot 0)$ & 1 in 62 \\
\hline $\begin{array}{l}1969 \\
\text { Rotunda } \\
\text { Coombe } \\
\text { National }\end{array}$ & $\begin{array}{l}5,299 \\
5,507 \\
5,360\end{array}$ & $\begin{array}{l}84 \\
70 \\
86\end{array}$ & $\begin{array}{l}1 \cdot 6(15 \cdot 9) \\
1 \cdot 3(12 \cdot 7) \\
1 \cdot 6(16 \cdot 0)\end{array}$ & $\begin{array}{l}1 \text { in } 63 \\
1 \text { in } 79 \\
1 \text { in } 62\end{array}$ \\
\hline Total & 16,166 & 240 & $1 \cdot 5(14 \cdot 8)$ & 1 in 67 \\
\hline $\begin{array}{l}\text { Total } \\
1968 / 69\end{array}$ & 31,853 & 491 & $1 \cdot 5(15 \cdot 4)$ & 1 in 65 \\
\hline
\end{tabular}

If the sex ratio is taken as $1: 1$, the number of like-sex dizygotic twin pairs would be expected to be the same as the observed number of unlike-sex twins. The number of monozygotic twins is then obtained by subtracting the number of dizygotic from the total of all twins.

Applying Weinberg's method to the Irish twinning population in 1969-70, there were 1,652 sets of twins, of whom 610 sets were of unlike sex and 1,042 were of like sex (Table XI). If the likelihood of births being male or female is taken as a 1:1 ratio, then the number of dizygotic twins should be $610 \times 2$, or 1,220 sets of dizygotic twins. If there

TABLE $X$

TWINNING RATE BY AGE OF MOTHER IN DUBLIN MATERNITY HOSPITALS, 1963/69

\begin{tabular}{|c|c|c|c|c|c|c|c|c|c|}
\hline \multirow[b]{2}{*}{$\begin{array}{l}\text { Age of } \\
\text { Mother }\end{array}$} & \multicolumn{3}{|c|}{ National Maternity Hospital } & \multicolumn{3}{|c|}{ Rotunda Maternity Hospital } & \multicolumn{3}{|c|}{ National and Rotunda Hospitals } \\
\hline & $\underset{\text { Births }}{\text { All }}$ & $\underset{\text { Births }}{\text { Twin }}$ & $\begin{array}{c}\text { Rate per } \\
1,000\end{array}$ & $\underset{\text { Births }}{\text { All }}$ & $\underset{\text { Births }}{\text { Twin }}$ & $\begin{array}{c}\text { Rate per } \\
1,000\end{array}$ & $\underset{\text { Births }}{\text { All }}$ & $\begin{array}{l}\text { Twin } \\
\text { Births }\end{array}$ & $\begin{array}{c}\text { Rate per } \\
1,000\end{array}$ \\
\hline Under 20 & 1,337 & 7 & $5 \cdot 2$ & 2,057 & 18 & $8 \cdot 8$ & 3,394 & 25 & $7 \cdot 4$ \\
\hline $20-24$ & 8,079 & 106 & $\begin{array}{l}13 \cdot 1 \\
(1 \text { in } 75)\end{array}$ & & & & 16,761 & 208 & $\begin{array}{l}12.4 \\
\text { in } 81)\end{array}$ \\
\hline 25-29 & 9,907 & 171 & $17 \cdot 3$ & 11,633 & 176 & $15 \cdot 1$ & 21,540 & 347 & $16 \cdot 1$ \\
\hline $30-34$ & 7,607 & 201 & $26 \cdot 4$ & 7,912 & 182 & $23 \cdot 0$ & 15,519 & 383 & $24 \cdot 7$ \\
\hline 35-39 & 5,560 & 121 & $21 \cdot 8$ & 4,683 & 143 & & 10,243 & 264 & \\
\hline $40+$ & 2,662 & 61 & $\begin{array}{c}22 \cdot 9 \\
(1 \text { in } 43)\end{array}$ & 1,841 & 43 & $\begin{array}{c}23 \cdot 4 \\
(1 \text { in } 43)\end{array}$ & 4,503 & 104 & $(1$ in 43$)$ \\
\hline All ages & 35,152 & 667 & $\begin{array}{c}19 \cdot 0 \\
(1 \text { in } 52)\end{array}$ & 36,808 & 664 & $\begin{array}{c}18 \cdot 0 \\
(1 \text { in } 55)\end{array}$ & 71,960 & 1,331 & $\begin{array}{c}18 \cdot 5 \\
(1 \text { in } 54)\end{array}$ \\
\hline
\end{tabular}

Includes twin births in which one or both twins were dead-born. 
TABLE XI

CALCULATED NUMBERS OF MONOZYGOTIC AND DIZYGOTIC TWINS IN IRELAND AND TWINNING RATES IN EACH AGE GROUP, 1969/70

\begin{tabular}{|c|c|c|c|c|c|c|c|c|}
\hline \multirow{2}{*}{$\begin{array}{c}\text { Type of } \\
\text { Twinning }\end{array}$} & \multicolumn{8}{|c|}{ Age at Maternity } \\
\hline & Under 20 & $20-24$ & $25-29$ & $30-34$ & $35-39$ & $40+$ & Unknown & Total \\
\hline $\begin{array}{l}\text { Like sex } \\
\text { Unlike sex }\end{array}$ & $\begin{array}{r}14 \\
9\end{array}$ & $\begin{array}{r}160 \\
76\end{array}$ & $\begin{array}{l}299 \\
144\end{array}$ & $\begin{array}{l}288 \\
190\end{array}$ & $\begin{array}{l}223 \\
148\end{array}$ & $\begin{array}{l}55 \\
42\end{array}$ & $\begin{array}{l}3 \\
1\end{array}$ & $\begin{array}{r}1,042 \\
610\end{array}$ \\
\hline Total & 23 & 236 & 443 & 478 & 371 & 97 & 4 & 1,652 \\
\hline $\begin{array}{l}\text { Number } \\
\text { Monozygotic } \\
\text { Dizygotic }\end{array}$ & $\begin{array}{r}5 \\
18\end{array}$ & $\begin{array}{r}84 \\
152\end{array}$ & $\begin{array}{l}155 \\
288\end{array}$ & $\begin{array}{r}98 \\
380\end{array}$ & $\begin{array}{r}75 \\
296\end{array}$ & $\begin{array}{l}13 \\
84\end{array}$ & $\begin{array}{l}2 \\
2\end{array}$ & $\begin{array}{r}432 \\
1,220\end{array}$ \\
\hline Total & 23 & 236 & 443 & 478 & 371 & 97 & 4 & 1,652 \\
\hline $\begin{array}{l}\text { Rates } \\
\text { Monozygotic } \\
\text { Dizygotic }\end{array}$ & $\begin{array}{r}(1 \cdot 3) \\
4 \cdot 6\end{array}$ & $\begin{array}{l}3.0 \\
5 \cdot 5\end{array}$ & $\begin{array}{l}4 \cdot 3 \\
8 \cdot 0\end{array}$ & $\begin{array}{r}3 \cdot 5 \\
13 \cdot 4\end{array}$ & $\begin{array}{r}4 \cdot 0 \\
15 \cdot 7\end{array}$ & $\begin{array}{l}(1 \cdot 7) \\
11 \cdot 1\end{array}$ & $\begin{array}{l}(3 \cdot 2) \\
(3 \cdot 2)\end{array}$ & $\begin{array}{r}3 \cdot 5 \\
10 \cdot 0\end{array}$ \\
\hline Total & $5 \cdot 8$ & $8 \cdot 5$ & $12 \cdot 3$ & $16 \cdot 8$ & $19 \cdot 6$ & $12 \cdot 8$ & $(6 \cdot 4)$ & $13 \cdot 4$ \\
\hline
\end{tabular}

The rates in brackets are based on less than 15 twin pairs.

were 1,220 dizygotic twins then there must have been 1,652-1,220,or 432 sets of monozygotic twins, i.e., $26 \%$ of twin sets were monozygotic and $74 \%$ dizygotic. A more complex formula can be used to take account of the slightly more frequent male than female births but the difference is small.

It can be seen from Table XI and the Figure that the increase in twinning with the age of the mother in Ireland, as elsewhere, is due to the increase of dizygotic twins. Monozygotic twin rates vary a little about the rate of $3 \cdot 5$ per 1,000 maternities due to the small numbers. A monozygotic rate of about $3 \cdot 5$ per 1,000 maternities is the usual rate found in other countries.

The observation that multiple births follow the injection of pituitary gonadotropins suggests that the release of two or more eggs from the ovary is due to an increased release of gonadotropins from the pituitary. The effect of an increasing pituitary hormone level could account for the increased risk of dizygotic twinning up to the age of 35-39, and would also account for the mechanism whereby certain women are genetically more inclined to produce twins (Weinberg, 1909; Milham, 1964; Wyshak and White, 1965).

In the United States, dizygotic twinning in each age group is more common among the Negro population than among the white population (Heuser, 1964). A study of twinning in a rural community in western Nigeria has shown a rate of 48 per 1,000 maternities and is the highest rate on record (Nylander, 1970). Dizygotic twinning rates are low among the oriental people, for instance the Japanese (Komai and Fukuoka, 1936). It is perhaps

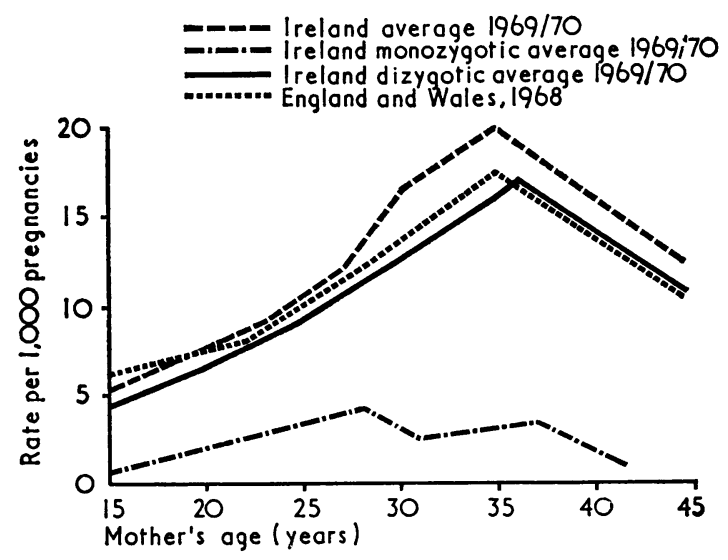

FIGURE-Twinning rates in Ireland and England and Wales.

significant that breast cancer is uncommon among the Japanese and oriental people and the breast is also under the influence of the pituitary gonadotropin hormone (Segi and Kurihara, 1962).

\section{CONCLUSION}

The twinning rate in the Republic of Ireland is higher than in other countries of Europe, although the rate is falling. The high twinning rate in the Republic of Ireland compared with England and Wales is due in approximately equal parts to a higher twinning rate at each age group in Ireland than in England and Wales and to the relatively large numbers of children born to older mothers. The higher proportion of pregnancies among older mothers in Ireland is due to the late average age of marriage and the high fertility after marriage. 
In Ireland the average age of marriage is becoming lower and women are having, on average, smaller families, so we can expect that the twinning rate will go on falling as a higher proportion of maternities occur at an earlier age.

Dr. M. Elian, neurologist, Beilinson Hospital, Israel, first drew our attention to the fact that Ireland had the highest twinning rate for all countries in which the rates had been reported. We should like to thank Mr. T. Linehan, Director of the Central Statistics Office, for his advice and co-operation with this study, and also Mr. A. Kumar, of the Office of Population Censuses and Surveys, Somerset House, London, for information about twinning rates in England and Wales, and Dr. G. C. R. Carey, of the Ministry of Health and Social Services, Belfast, for information about the twinning rates in Northern Ireland. Professor M. D. McCarthy, President of University College, Cork, assisted with this study, and the Registrar General (Ard Chláraitheoir) provided twinning rates for the four provinces for the year 1969. Dr. E. Lillie, Master of the Rotunda Hospital, Dr. W. Gavin, Master of the Coombe Hospital, and Dr. Declan Meagher, Master of the National Maternity Hospital, provided the twinning rates at the three Dublin maternity hospitals. Professor Kieran O'Driscoll, formerly Master of the National Maternity Hospital and a member of the Medico-social Research Board, gave us great assistance in the preparation of the paper. Dr. Brendan Walsh, of the Economic and Social Research Institute, Dublin, supplied the tables on age at marriage and family size. Sir Richard Doll, Regius Professor of Medicine, Oxford, and Mr. Richard Peto, of his Department, provided most valuable statistical advice.

\section{REFERENCES}

Bulmer, M. G. (1960). The twinning rate in Europe and Africa. Ann. hum. Genet., 24, 121.

Heuser, R. L. (1964). Multiple births, 1964 (United States). National Centre for Health Statistics, Series 21, 14.

KomaI, T., and Fukuoka, G. (1936). Frequency of multiple births among the Japanese and related peoples. Amer. J. phys. Anthropol., 21, 433.

MilhaM, S. (1964). Pituitary gonadotropin and dizygotic twinning. Lancet, 2, 566.

MOONEY, D. M. (1970). J. Irish med. Ass., 63, 391.

NyLANDER, P. P. S. (1970). Twinning in a rural community in Western Nigeria. Its relation to maternal age and parity. Bull. int. Epid. Ass., 191.

Segi, M., and Kurihara, M. (1962). Cancer Mortality for Selected Sites in 24 Countries, No. 2. (1958-1959). Department of Public Health, Tohoku University, Japan.

WeinBerg, W. (1909). Zur Bedeutung der Mehrlings- 9 geburten für die Frage der Bestimmung des Geschlechts. Arch. Rass. u. Ges. Biol., 6, 28.

WyshaK, G., and White, C. (1965). Genealogical study of human twinning. Amer. J. publ. Hlth., 55, 1586.

Yerushalmy, J., and Sheerar, S. E. (1940). Studies ob $\vec{\varphi}$ twins. I. The relation of order of birth and age of $N$ parents to the frequency of like-sexed and unlike-sexeffi twin deliveries. Hum. Biol., 12, 95.

ZelenY, C. (1921). The relative numbers of twins and triplets. Science, 53, 262. 